\title{
Da arqueologia portuguesa à arquitetura brasileira
}

Joana Mello*

Ricardo Severo: entre o elogio e a crítica

A imagem de Ricardo Severo legada à posteridade foi em larga medida forjada pelo próprio engenheiro luso e por biógrafos encomiastas ${ }^{1}$, em geral compatriotas, condiscípulos e admiradores. Para estes, Severo foi a figura de maior destaque no ambiente científico, artístico e político dos dois países em que viveu - o Portugal nativo e a ex-Colônia tomada por ele como segunda pátria - seja pelo caráter multifacetado de sua obra, seja pelo brilhantismo com que teria desempenhado as mais diversas atividades ao longo da vida, como arqueólogo, antropólogo, cientista, historiador, escritor, arquiteto, artista e construtor. Homem de ação e de cultura, dono de invejável erudição e de uma personalidade inquieta que faria dele um publicista contumaz, Severo teria desempenhado com nobreza o lugar de patriarca da colônia portuguesa no Brasil, incentivando o movimento associativo luso-brasileiro e a ele dedicando grande parte de seu esforço intelectual. Ao renome como mestre da arquitetura "tradicional" no Brasil se somaria a destacada atuação profissional ao lado de Francisco de Paula Ramos de Azevedo no requisitado Escritório Técnico, na Companhia Iniciadora Predial e no Liceu de Artes e Ofícios de São Paulo. No quadro pintado por esses biógrafos - destoante da leitura especializada ${ }^{2}$ posterior, diga-se de passagem - Severo teria encontrado em Ramos de Azevedo um companheiro da "causa tradicionalista”, podendo a ele ser igualado na transformação da fisionomia arquitetônica da antiga Vila de Piratininga. Renovação eclética do cenário urbano e campanha em prol das artes tradicionais surgindo assim como atividades simultâneas em sua obra arquitetônica.

* doutoranda da FAU-USP e professora da FAU-UniABC

1 Carlos Malheiro Dias, "Discurso do Sr. Carlos Malheiro Dias". DIAS, Carlos Malheiro. Homenagem a Ricardo Severo. São Paulo: Companshia Melhoramentos, 1932, pp. 8-17; "Discurso do Dr. Roberto Moreira”. Idem, ibidem, pp. 21-28; "Discurso do Dr. Marques da Cruz." Idem, ibidem, pp. 31-36;

2 Lemos, Carlos A. C. Ramos de Azevedo e seu Escritório. São Paulo: Pini, 1993; Carvalho, Maria Cristina Wolff. Ramos de Azevedo. São Paulo: Edusp, 2000. 
Na bibliografia sobre a história da arquitetura brasileira há também um lugar obrigatório, ainda que restrito, para a personalidade e atuação de Severo. Em linhas gerais, os historiadores tenderam a atribuir um papel conservador à "cruzada tradicionalista" empreendida pelo engenheiro luso em prol da recuperação das artes e da arquitetura do período colonial. De um lado, Severo aparece como principal mentor teórico do movimento neocolonial, orador apaixonado, precursor da pesquisa em torno de uma suposta nacionalidade artística brasileira, patrocinador dos primeiros estudos in loco da arquitetura colonial feita no país, além de um de seus maiores colecionadores e defensores contra a vaga acadêmica e modernizadora que se alastrava no campo das construções desde os últimos decênios do século XIX. De outro, o engenheiro surge como dos maiores dilapidadores e falsificadores da arquitetura colonial; como restaurador inepto e arquiteto mediano, responsável pela produção de mais uma variante do ecletismo europeu no já carregado panorama historicista local (a diferença ficando por conta do sotaque português) e pela valorização duvidosa, quando não manipuladora, de elementos de arquitetura colonial e portuguesa, civil e religiosa, que misturaria séculos e procedências, incongruentes no tempo, no espaço e no estilo. Ocupando na historiografia um lugar semelhante ao do próprio neocolonial, o principal mérito de Severo teria sido o ter aberto caminho para a retomada, estudo e preservação de uma arquitetura pretérita; caminho este que só seria corretamente percorrido a partir dos anos 1930 com os arquitetos modernos cariocas. ${ }^{3}$

Se entre os admiradores predominou o culto de uma personalidade absolutamente singular em seu tempo, destacada de seu contexto, para os críticos a importância do engenheiro português se restringiu a um episódio circunscrito (e menor) da arquitetura brasileira. As imagens convencionais de seu papel histórico - ora apologéticas, ora críticas, ora auto-indulgentes - mostram o quão inespecífica é a classificação pura e simples de Severo como "conservador", "nacionalista" ou "tradicionalista". Participando ativamente

3 Costa, Lucio. "Muita construção, alguma arquitetura e um milagre" (1951). Lucio Costa: registro de uma vivência. São Paulo, Empresa das Artes, 1995, pp. 164-165; Goodwin, Phillip L. Brazil Builds Architecture New and Old 1652-1942. New York, Museum of Modern Art, 1943; Mindlin, Henrique. Arquitetura Moderna no Brasil (1956). Rio de Janeiro, Aeroplano Editora, 1999; Bruand, Ives. Arquitetura Contemporânea no Brasil. São Paulo, Perspectiva, 1981; Lemos, Carlos A. C. Arquitetura Brasileira. São Paulo: Melhoramentos, 1979. 
do esforço de compreensão e definição da nação brasileira, o engenheiro português e sua obra ajudam a problematizar um período já tão estudado de nossa história intelectual, as décadas de 1910, 1920 e 1930, apontando para a diversidade de projetos em curso naquele momento. Afinal, a busca dos elementos fundantes de uma nação, a constituição de uma identidade capaz de particularizá-la no confronto com o outro, as tentativas de compreensão de sua inserção internacional e as possibilidades futuras eram preocupações recorrentes para os intelectuais que no começo do século XX se engajaram nos mais diversos movimentos nacionalistas ${ }^{4}$. Se as preocupações eram comuns, as respostas ou saídas por eles elaboradas eram diferentes e até divergentes, o que poderia ser explicado levando-se em conta os parâmetros a partir dos quais elaboravam suas visões de mundo, o arsenal analítico que manejavam e a missão social e política que cada um deles se atribuía. Identificar e analisar esses parâmetros em Ricardo Severo pode ajudar a ampliar a compreensão do debate artístico daquele período, tornando mais complexa e matizada a leitura da produção arquitetônica eclética, neocolonial ou moderna.

Dessa forma, para compreender as idéias de Severo, bem como precisar o sentido de suas propostas e atuação pública, é preciso recuperar algo de sua biografia e itinerário intelectual, buscando sua inscrição no tempo e na sociedade que lhe foi dado viver. De modo geral, os textos escritos pelo engenheiro português sugerem a existência de dois momentos em sua vida: o primeiro em Portugal, entre 1884 e 1908, no qual domina quase que exclusivamente o interesse pela arqueologia; e o segundo no Brasil, entre 1908 e 1940, quando o engenheiro diversifica suas atividades, dedicando-se à luta republicana, à valorização do legado luso no Brasil, à unificação e fortalecimento da colônia portuguesa no país e à arquitetura. Se a nítida demarcação desses dois períodos corresponde a uma mudança significativa nos focos de atuação de Severo, ela também perfila uma linha de continuidade marcada pelo compromisso com as tradições lusitanas e as idéias raciais-evolucionistas. Seus escritos e projetos, imbuídos de tom polêmico e programático, eram característicos de um nacionalista atormentado pelas transformações geopolíticas internacionais e pelo modo como estas incidiam sobre as realidades brasi-

4 Candido, Antonio. “Uma palavra instável”. Vários Escritos. São Paulo, Duas Cidades, 3a edição, 1995, p. 293-305. 
leira e portuguesa na virada do século XX. Nota-se que o discurso do engenheiro, sem projetar uma trajetória individual absolutamente coerente e perfeitamente encadeada no tempo ${ }^{5}$, dialoga com o contexto social, político e cultural em que foi produzido, sendo possível recompor historicamente os sentidos de seu controverso "nacionalismo" e "tradicionalismo".

\section{Um mundo português em ruínas}

Ricardo Severo da Fonseca e Costa (Lisboa, 1869

- São Paulo, 1940) viveu as profundas transformações políticas, econômicas, sociais, científicas e culturais que definiram a chamada "era dos impérios" ${ }^{6}$ Como se sabe, os anos de 1870 a 1914 foram marcados por intensas disputas entre Estados imperialistas jovens e velhos pela dominação de mercados consumidores mundiais e territórios coloniais na África e no Oriente. Estas disputas, ocasionadas por um "tipo curioso de crise econômica"7 implicaram uma mudança profunda no antigo arranjo de forças entre as potências do período, além de sinalizar o advento de um novo tipo de imperialismo. ${ }^{8}$

Portugal, país essencialmente agrário, ocupava um lugar bastante frágil nessa nova ordem mundial. Seu domínio colonial, principalmente na África, se via ameaçado tanto pelas fortes pressões comerciais britânicas, quanto pela dificuldade administrativa de transformar os antigos "enclaves" africanos em "colônias". Ameaça cuja gravidade só pode ser medida levando-se em conta que a manutenção e controle das colônias africanas não representava nesse momento apenas a possibilidade do império reconquistar o posto de entreposto comercial de produtos tropicais, mas também a "garantia da conservação do próprio território metropolitano" e sua independência como nação, abalada então pelo ameaça real de uma nova União Ibérica ${ }^{9}$. A esse quadro externo complexo somavam-se internamente su-

5 Bourdieu, Pierre. "A ilusão biográfica”. RazõesPráticas. Sobre a Teoria daAção. Campinas, Papirus, 1996.

6 Hobsbawm, Eric J. A Era dos Impérios. São Paulo,:Paz e Terra, 1988.

7 Arendt, Hannah. As Origens doTotalitarismo. São Paulo, Companhia das Letras, 1989, pp. 147-187.

8 Thomaz, Omar Ribeiro. Ecos do Atlântico Sul:Representações sobre oTerceiro Império Português. Rio de Janeiro, Editora UFRJ/ FAPESP, 2002, p. 38.

9 Idem, ibidem, p. 30-80. 
cessivas crises, cujo foco central era a própria Monarquia, desgastada por sua orientação econômica - que privilegiava a atividade agroexportadora em detrimento do pequeno produtor rural e da indústria nacional -, pela incapacidade de administrar os territórios coloniais e por uma sensível queda no nível de vida da população, sobretudo entre as camadas mais pobres e a pequena e média burguesia. ${ }^{10}$

0 quadro de crise generalizada desembocaria em uma série de protestos contra a Coroa ${ }^{11}$, que ecoavam um dos temas centrais dos debates políticos-culturais da Europa deste período: a decadência e a salvação. ${ }^{12}$ Em Portugal, esse será o tema dileto do movimento republicano que, em consonância com outros movimentos de redenção em curso no continente, via na busca das origens das nações, dos traços primitivos das raças fundadoras e das formas ancestrais de governo, o único caminho possível de retomada da grandeza nacional frente às ameaças internas e externas de desestruturação. ${ }^{13}$ Era a partir dessa investigação das origens que se acusava a artificialidade da Monarquia e o declínio do império português, afirmando-se a República como única possibilidade de salvação nacional, seja por constituir o ápice da evolução humana no âmbito político, seja por emanar diretamente do caráter étnico e, portanto, da natureza de seu povo. ${ }^{14}$

0 núcleo de oposições republicanas à monarquia, que foi gradualmente se constituindo desde meados do século XIX, tinha como canais principais de divulgação e propaganda os meios de comunicação de massa e as instituições de pesquisa e ensino superior em Coimbra, Lisboa e Porto. ${ }^{15}$ Mais do que um simples projeto político, o movimento republicano em Portugal se configurou como um ideário social, espiritual e cultural que fomentava uma visão de mundo marcada pelo anticlericalismo, cientificismo, evolucionismo

10 Cartroga, Fernando. O Republicanismo em Portugal. Da formação ao 5 de outubro. Coimbra, Faculdade de Letras, 1991, pp. 12-19.

11Idem, ibidem, pp. 12-19.

12 Oliveira, Lucia Lippi, "Decadência e salvação". A Questão Nacional na Primeira República. São Paulo, Brasiliense, 1990, pp. 49-73.

13 Arendt, Hannah. Op. cit., pp. 147-187.

14 Catroga, Fernando, Op. cit.., p. 45.

15 Ramos, Rui. “A nação intelectual”. RAMOS, Rui. A segunda fundação (1890-1926). MATTOSO, José (org.) História de Portugal. Lisboa, Círculo de Leitores, 1994, pp. 43-67. 
e nacionalismo. ${ }^{16}$ Não é a toa que, entre o final do século XIX e os anos 1930, o movimento coincida com o período de supervalorização das tradições lusitanas e de "construção da nação" num sentido amplo, e que os principais símbolos, instituições e personagens que dão identidade ao país ainda hoje tenham sido definidos nesse período. ${ }^{17}$

Ricardo Severo participa do movimento republicano português em seus vários âmbitos. Do ponto de vista estritamente político, envolve-se ativamente na revolta do Porto de $1891^{18}$ - participação que lhe custaria um período de exílio no Brasil - e produz entre $1910-1923^{19}$ uma série de conferências sobre a causa republicana. Nestas conferências postulava a partir da reconstituição histórica e arqueológica da nação portuguesa ser possível comprovar cientificamente que a República era a própria "síntese indissolúvel do caráter étnico, moral e social dessa nacionalidade, cujas origens se confundem com a história do próprio solo nacional, desde os períodos geológicos do 'Quaternário". ${ }^{20}$ Tanto esta afirmação como sua atuação só podem ser entendidas neste contexto, em particular no tocante ao veio mais profícuo de sua militância republicana: a arqueologia.

\section{Política de redenção: republicanismo e arqueologia}

A primeira notícia do envolvimento de Ricardo Severo com o mundo científico português, sua participação no IX Congresso de Antropologia e Arqueologia Pré-histórica (Lisboa - 1880) ${ }^{21}$, coincide com a conjuntura de queda no nível de vida da população e radicalização dos protestos contra a Coroa. 0 congresso foi particularmente marcante para o engenheiro. Primeiro, porque foi naquela ocasião que

16 Catroga, Fernando. Op. cit., p. 197.

17 Ramos, Rui. Op. cit, pp. 565-595.

18 Sobre a revolta de 1891 do Porto ver Catroga, Fernando, Op. cit., p. 113135.

19 Ramos, Rui. op. cit.

20 Severo, Ricardo, “Origens da nacionalidade portuguesa”. Revista Portuguesa. São Paulo, 1937, tomo I, fasc. 5, p. 336.

21 Grande Enciclopédia Portuguesa e Brasileira. Rio de Janeiro/ Lisboa: Editorial Enciclopédia, 1945, pp 618-619. A data suscita dúvida, dado que em 1880 Severo contava apenas com 11 anos. É nesse mesmo ano, contudo, que Severo passa a editar, em parceria com Alberto Ortigão Miranda, o jornal semanal $O$ Instrutivo, publicado até pelo menos 1883, cujos exemplares foram estão em posse do neto de Severo, Luis Roberto Severo Lebeis. 
ele tomou contato com as pesquisas de Nery Delgado (18351908) ${ }^{22}$ e de Carlos Ribeiro (1813-1882) ${ }^{23}$, cuja influência seria decisiva em sua vida profissional; segundo, porque o evento ocorreu no ano em que se festejava o centenário da morte de Luis de Camões, cujas comemorações ensejaram o fortalecimento do até então incipiente movimento republicano português. ${ }^{24}$

Severo ingressou na Academia Politécnica do Porto ${ }^{25}$ em 1884, formando-se em Engenharia Civil de Obras Públicas em 1890 e em Engenharia Civil de Minas em 1891. Não se sabe se constava destes cursos uma introdução à pesquisa arqueológica, ainda que em Portugal a matéria tenha se vinculado ao estudo de minas, geologia e ciências naturais $^{26}$. Também não se pode afirmar ao certo se a opção de Severo pelo curso de Minas foi a extensão natural de um interesse prematuro pela arqueologia, anunciado desde o congresso de 1880. Percebe-se, entretanto, que nos anos em que freqüentou a Academia, a matéria assumiu a prioridade entre as suas atividades acadêmicas e profissionais e que seu interesse pela disciplina era compartilhado com um grupo de intelectuais republicanos portuenses. ${ }^{27}$ Com esses, desenvolveu uma série de iniciativas em que se manifesta o

22 Sobre Nery Delgado ver a biografia escrita por Ana Carneiro no site do Instituto Camões, http://www.instituto-camoes.pt/cvc/ciencia/p37.html e no site do Instituto Geológico e Mineiro de Portugal http.//www.igm.pt/ document/centros/museu_geologico/biografias/nery_delgado.htm

23 Sobre Carlos Ribeiro ver a biografia escrita por Vanda Leitão no site do Instituto Camões, http://www.intituto-camoes.pt/cvc/ciencia/p38.html e Severo, Ricardo. "Carlos Ribeiro". Revista de Ciências Naturais e Sociais. Porto, 1897/98, v. V, fasc. 20, p. 153-187.

24 Catroga, Fernando. Op. cit.

25 Sobre a Academia Politécnica do Porto ver: Santos, Cândido dos. Universidade do Porto - raizes e memória da instituição. Porto, Universidade do Porto, s.d.; Rodrigues, Maria de Lurdes. Os Engenheiros em Portugal: Profissionalização e Protagonismo. Oeiras, Celta Editora, 1999 e os sites Engenharia do século XX http://www.engenharia.com.pt; e Universidade do Porto/ Faculdade de Engenharia http://sifeup.fe.up.pt.

26 Martins, Manuela. "Martins Sarmento e a arqueologia”. Revista Guimarães. Guimarães, 1995, n. 105, pp. 127-138. Casa Sarmento http:// www.csarmento.uminho.pt/docs/ndat/rg/RG105_08.pdf.

27 Faziam parte deste grupo Júlio de Matos, Wenceslau de Lima, Basílio Teles, Alfredo Xavier Pinheiro, João Barreira, Artur Augusto da Fonseca Cardoso, Antonio Augusto da Rocha Peixoto, entre outros. Severo, Ricardo. "Origens da nacionalidade brasileira", 1930, tomo I, fasc. I, pp. 58- 62; Severo, Ricardo. op. cit., 1932, Ricardo Severo, "Recordando" - oração pronunciada no Centro Republicano Português de São Paulo, em 31 de janeiro de 1937. Revista Portuguesa. São Paulo, 1937, tomo I, fasc. 5, p. 372-375. 
compromisso duplo: de um lado, com a pesquisa científica, de outro, com o projeto político republicano de redimir a pátria decaída.

Exemplo da atuação político-científica do grupo é a fundação da Sociedade Carlos Ribeiro ${ }^{28}$ (1887- 1898). Para os jovens, essa personalidade híbrida de oficial do exército e cientista, era um dos pioneiros da geologia, paleontologia, paleoetnologia e arqueologia em Portugal, seu trabalho servindo como exemplo de pesquisa científica. Valendo-se de supostas descobertas arqueológicas feitas por Ribeiro às margens do Tejo, a sociedade instituída em sua homenagem buscava endossar sua principal tese: a origem pré-histórica e independente da nacionalidade portuguesa.

Carlos Ribeiro, no entanto, não era a única referência teórica dos membros da sociedade. 0 trabalho dos arqueólogos e etnólogos vimarenses Francisco Martins Sarmento ${ }^{29}$ (1833-1899) e Alberto Sampaio (1841-1908) ${ }^{30}$, também é digno de nota, sobretudo no que diz respeito aos estudos comparativos que o primeiro realizou nos "castros" e "cividades" da região do Minho, que comprovariam não só a antigüidade destas acrópoles fortificadas, como a origem pré-romana e pré-celta do povo português. Partindo dessas descobertas, estes cientistas se contrapunham tanto àqueles que defendiam o celtismo e orientalismo na origem desse povo, quanto àqueles que, como o historiador e romancista Alexandre Herculano (1810-1877), afirmavam a "inexistência de relações genealógicas entre os portugueses e as populações pré ou proto-históricas, especialmente com os Lusitanos". ${ }^{31}$

28 Sobre a Sociedade Carlos Ribeiro ver Grande Enciclopédia Portuguesa e Brasileira. Rio de Janeiro/ Lisboa: Editorial Enciclopédia, 1945, p. 583584.Ver Peixoto, Rocha. "A Sociedade Carlos Ribeiro", Revista de Ciências Naturais e Sociais. Porto, 1898, v. V, n. 20, Idem, "A Sociedade Carlos Ribeiro”. Portugália. Porto, 1899, tomo I, fasc. 1, p. 155.

29 Sobre Francisco Martins Sarmento ver o site da Casa Sarmento http://www.csarmento.uminho.pt/sms.asp e do Museu Martins Sarmento http://www.geira.pt/MSMartinsSarmento. 0 primeiro artigo de Ricardo Severo de que temos notícia, escrito em co-autoria com Fonseca Cardoso, segue os mesmos passos e premissas da pesquisa desenvolvida por Sarmento nas estações pré-históricas de Briteiros, Citânia e Sabroso. Severo, Ricardo, e Cardoso, Fonseca. "Notícia arqueológica sobre o Monte da Cividade”. Revista Guimarães, 1886, http://www.csarmento. uminho.pt/sms.asp.

30 Sobre Alberto Sampaio ver o site do Museu Alberto Sampaio http:// www.geira.pt/malbertosampaio.

31 Martins, Manuela. Op. cit, p. 7. 
Outros dois exemplos importantes da atuação do grupo de Severo são: a Revista de Ciências Naturais e Sociais ${ }^{32}$ e a Portugália. Materiais para o estudo do povo português. Fundada em 1890 como o "principal instrumento de ação" da Sociedade Carlos Ribeiro, a Revista de Ciências Naturais e Sociais era dirigida por Rocha Peixoto, Ricardo Severo ${ }^{33}$ e Wenceslau de Sousa Pereira Lima (1858-1919) ${ }^{34}$, dedicandose a publicação de estudos sobre paleoetnologia, etnologia, etnografia, geologia, botânica, zoologia e arqueologia, a maioria deles dedicados à pré-história da nacionalidade portuguesa. A revista circulou por oito anos, sendo seu encerramento justificado em nome de uma nova publicação que a suplantaria em alcance e envergadura: a Portugália.

A maioria dos colaboradores da Revista de Ciências Naturais e Sociais está presente na Portugália, que mantém e amplia o projeto editorial anterior. Em consonância com o discurso nacionalista do grupo de republicanos ao qual pertencia, Severo afirmava que o objetivo central da publicação era o de levantar os "verdadeiros elementos da vida e do caráter nacional, a nossa razão de ser e da nossa história", o "substractum da nacionalidade", para inaugurar "um novo período de renascença dentro da própria nacionalidade, que [era] também a renascença de um velho povo". ${ }^{35}$

De volta a Portugal, depois do período de exílio no Brasil (1891/92-1897/98), Severo lidera a criação da Portugália. Nesta nova iniciativa, o engenheiro era ao mesmo tempo proprietário, diretor e editor da publicação, tendo escrito dezenas de artigos, quase todos dedicados à arqueologia. Nos que abordava as origens da nacionalidade portuguesa, o engenheiro seguia as trilhas abertas por Ribeiro e Sarmento, defendendo que do ponto de vista mesológico

32 Sobre os objetivos gerais da Revista de Ciências Naturais e Sociais ver Telles, Bazílio. "Introdução". Revista de Ciências Naturais e Sociais. Porto, 1890, vol I, fasc. 1, pp. 1-5 e Peixoto, Rocha. "Publicações periódicas" Portugália. Porto, tomo I, fasc. 1, 1899, p. 176.

33 Severo aparece como diretor da revista em todos os fascículos, mas colaborou efetivamente, escrevendo artigos, notícias e/ou resenhas, nos fascículos 1 a 4 (volume 1/1890); fascículos 5 a 8 (volume 2/1893) e fascículos 17 a 20 (volume 3/1897-98). Nos fascículos 9 a 12 (volume 2/1894-95) e fascículo 13 a 16 (volume 4/1895-96), Severo pode não ter participado por ainda estar em São Paulo.

34 Sobre Wenceslau de Sousa Pereira de Lima ver o site do Instituto Geológico e Mineiro de Portugal http://www.igm.pt/document/centros/ museu_geologico/biografias/wenceslau.htm.

35 Severo, Ricardo. "Prospecto e Programa Geral". Portugália. Porto, tomo I, fascículo 1, 1899, p. VII 
"a constituição do território [português] como unidade geográfica independente” era garantida pela topografia e hidrografia, cuja constituição teria isolado Portugal do resto da Europa; e que do ponto de vista racial, a nacionalidade portuguesa tinha como "célula matriz" o "ibero-ligúrico". A defesa da pureza racial portuguesa era, ao mesmo tempo, essencial e problemática em seu discurso. Essencial, por ser naquele momento, ao lado da unidade territorial, um dos atributos decisivos da afirmação da nação e de sua independência. Problemática, na medida em que o ideal de pureza racial era turvado pelo fato, admitido pelo próprio engenheiro, de que a Península Ibérica tinha sido palco das mais diversas migrações, sendo sua população "sob o ponto de vista da sua composição étnica [...] assaz mesclada”. Característica que indicaria a degeneração da nacionalidade e, portanto, a impossibilidade de concretização do projeto de redenção da nação em declínio. Era para escapar da ameaça da mestiçagem e do perigo de desintegração nacional que Severo afirmava, ainda que de modo contraditório e forçado, que os diversos povos que passaram pelo território português desde a pré-história pertenciam ao mesmo grupo racial lusitano ou não tinham um papel de relevo na constituição daquela nacionalidade. ${ }^{36}$

Depois de vinte e quatro anos dedicados à arqueologia, Severo interrompe aquele que declarou ter sido o trabalho mais importante de sua vida: a Portugália. A revista deixa de circular em 1908, quando Severo se vê obrigado a abandonar sua terra natal, em virtude de dificuldades financeiras advindas da vida suntuosa de editor de uma revista de luxo, mas de público reduzidíssimo e agravada pela má administração dos bens que conquistara em sua primeira estadia em São Paulo. Na medida em que o encerramento de sua atuação como arqueólogo não significou o arrefecimento de sua fé republicana, nem o abandono de seu interesse pela nacionalidade portuguesa, o engajamento de Severo conheceria outros desdobramentos no Brasil, convivendo com outras crenças e formas de atuação.

36 Para acompanhar passo a passo os argumentos do engenheiro sobre o tema ver "Origens da Nacionalidade Portuguesa" (1911). Revista Portuguesa. São Paulo, 1930, tomo I, fasc. I, pp. 1- 4; “Origens da Nacionalidade Portuguesa” (1911). Revista Portugal. São Paulo, 1930, tomo I, fasc. 2, pp. 100-114; "Origens da Nacionalidade Portuguesa" (1911). Revista Portuguesa. São Paulo, 1936, tomo I, fasc. 4, pp. 253-259; “Origens da Nacionalidade Portuguesa” (1911). Revista Portuguesa. São Paulo, 1937, tomo I, fasc. 5, pp. 329-337. 


\section{Laços de família e atuação profissional}

Ricardo Severo veio ao Brasil pela primeira vez em $1891 / 92^{37}$, engrossando a massa de imigrantes portugueses que, entre o século XIX e XX, tiveram o país como destino $^{38}$. Representante bem sucedido das camadas médias portuguesas ligadas ao comércio e à indústria, é possível que sua opção tenha sido animada pela vinda de outros republicanos igualmente perseguidos pela revolta do Porto de $1891^{39}$ ou que tenha pesado a amizade com o colega dos tempos da Academia Politécnica, o engenheiro brasileiro Carlos Villares. Tanto nessa primeira passagem quanto na posterior estadia definitiva no Brasil, chama a atenção a diversidade e prosperidade alcançada pelo engenheiro nos investimentos mais variados, comércio, construção civil, mercado financeiro e imobiliário ${ }^{40}$. Surpreendente também, desde a primeira estadia, sua rápida, sólida e marcante inserção, não só no âmbito protegido da colônia portuguesa, como nos meios sociais, empresariais e culturais paulistanos.

Severo se preocupou em promover, acima de suas convicções políticas, a união entre os imigrantes portugueses ao redor de uma única instituição, a Casa Portu-

37 Sobre esta primeira estadia ao Brasil há várias versões quanto às datas de chegada e partida de Severo: Gonçalves, Ana Maria do Carmo Rossi. A Obra de Ricardo Severo. São Paulo, FAU-USP, 1977; Lemos, Carlos A. C, Op. cit., 1993, p. 60, Rial, Mariana Fontes Pérez. Movimento ou Estilo: Estudos sobre a Arquitetura Neocolonial Paulistana. São Paulo, texto mimeografado, relatório final de pesquisa CNPq/FAUUSP, 2000; Severo, Ricardo. Discursos. Rio de Janeiro: Real Gabinete de Leitura, 1937, p. 5; Severo, Ricardo, Op. cit., 1930, p. 9.

38 Sobre a imigração portuguesa para o Brasil ver: Pereira, Miriam Halpern. A Politica de Imigração Portuguesa. Lisboa, A Regra do Jogo, 1981; Alencastro, Luiz Felipe de. "Proletários e Escravos". Novos Estudos CEBRAP. São Paulo, n. 21, 1988; Scott, Ana Silvia Volpi. "Verso e reverso da imigração portuguesa: o caso de São Paulo entre as décadas de 1820 e 1930”. Oceanos. Lisboa, out/dez 2000, n. 44, p. 127; Rowland, Robert. "Portugueses no Brasil independente: processos e representações”. Oceanos. Lisboa, out/dez 2000, n. 44, pp. 8-21; Venâncio, Renato Pinto. "A imigração portuguesa, 1822-1930", Oceanos. Lisboa, out/dez 2000, n. 44, p. 63; Lobo, Eulália Maria Lahmeyer. Imigração Portuguesa no Brasil. São Paulo: Hucitec, 2001.

39 Entre eles estavam: Basílio Teles, tenente Coelho, alferes Carlos Malheiro Dias e Ramalho Ortigão.

40 As informações sobre o patrimônio de Severo foram colhidas em entrevistas com a filha mais nova de Severo, Elisa Germano Severo, e no documento "Inventário e partilhas do espólio do dr. Ricardo Severo da Fonseca e Costa 1940-41", cedido pelo neto Luis Roberto Severo Lebeis. 
guesa ${ }^{41}$, e em aproximar as relações econômicas, políticas e culturais entre os dois países em que viveu, ${ }^{42}$ fazendo de si próprio uma espécie de patriarca da colônia portuguesa e um dos principais mentores do movimento associativo lusobrasileiro.

Os laços familiares tecidos por Severo no Brasil tiveram início em 1893, ano de seu casamento com Francisca Santos Dumont. 0 engenheiro fora apresentado à família Dumont por Carlos Villares que também havia se casado com uma das filhas do famoso "rei do café", Henrique Dumont. ${ }^{43}$ Portanto, passado apenas um ou dois anos de sua vinda ao país, o engenheiro se estabelece no seio da sociedade tradicional paulista, angariando a ascendência e o prestígio social que lhe seriam de grande valia para o resto da vida. Tal prestígio, entretanto, não seria fruto apenas de seu matrimônio.

Antes mesmo de se casar, Severo publicara um artigo sobre o Museu Sertório ${ }^{44}$ no jornal Correio Paulistano, no qual criticava a organização geral da instituição, apontando as deficiências em suas sessões, especialmente aquelas de-

410 programa da instituição está bem esboçado no artigo Severo, Ricardo. "A Casa Portuguesa em São Paulo”. Portugal. Rio de Janeiro, 1925, n.43, pp. XIX-XX.

42 As conferências, discursos e artigos em defesa do luso-brasileiro são: "As relações luso-brasileiras" (1916); "A missão dos portugueses". O Estado de S. Paulo. São Paulo, 5/12/1918. p. 3; "Relações LusoBrasileiras” (1919), conferência pronunciada na Câmara Portuguesa de Comércio de São Paulo; "Portugal-Brasil" (1920), conferência pronunciada no Automóvel Club em Homenagem à Colônia; "Imigração portuguesa no Brasil" (1925), conferência pronunciada na Câmara Portuguesa de Comércio de São Paulo, "Um prefácio para a 'Revista Portuguesa". Revista Portuguesa. São Paulo, 1930, tomo I, fasc. 1, p. III-VIII. e “Um 'Tombo' Luso-Brasileiro" (1937), conferência pronunciada no Real Gabinete Português de Leitura do Rio de Janeiro. Infelizmente só pudemos localizar o artigo "A missão dos portugueses no Brasil”, o prefácio escrito para a abertura da Revista Portuguesa e a conferência "Um 'Tombo' LusoBrasileiro".

430 filho mais velho de Henrique Dumont, formou-se pela Escola Politécnica do Rio de Janeiro, tendo trabalhado em 1881 na construção da estrada de ferro Mogiana, onde conheceu Eduardo Villares. Eduardo casou-se em 1885 Cocota Santos Dumont. Em 1886, Guilherme Villares, irmão de Eduardo, casou-se com Virginia Santos Dumont. Em 1887 chega ao Brasil Carlos Villares, irmão de Eduardo e Guilherme que se formou como engenheiro civil na Academia Politécnica do Porto e se casou com Gabriela Santos Dumont em 1891. Ribeiro, Anamaria Germano. A História da Família Dumont. São Paulo, texto impresso, 1998.

440 Museu Sertório foi o germe do atual Museu Paulista. Sobre a história do Museu Paulista e de seu acervo ver o site www.mp.usp.br. 
dicadas às ciências naturais, à etnografia, à arqueologia e à pré-história. 0 artigo é importante por confirmar a presença do engenheiro português em terras paulistanas a partir de 1892, e porque sua crítica refletia a atitude polemista e publicista comum ao círculo de intelectuais portuenses ao qual pertencia, apontando ainda o seu envolvimento precoce com a cidade que acabara de o acolher. Além disso, a polêmica gerada pelo artigo chegou aos ouvidos do então Secretário de Agricultura, Comércio e Obras Públicas, Alfredo Maia, que o apresentaria a seu parente e amigo, o engenheiro-arquiteto campineiro Francisco de Paula Ramos de Azevedo (1851-1928). ${ }^{45} 0$ episódio lhe renderia um emprego como auxiliar no escritório "do já então famoso engenheiro-arquiteto" e, ao mesmo tempo, o cargo de chefe da seção construtora do Banco União de São Paulo, "cuja carteira predial era [também] dirigida" por ele ${ }^{46}$.

A sociedade entre Ramos e Severo se estendeu por mais de vinte anos tendo extrapolado os limites do Escritório Técnico F. P. Ramos de Azevedo. Destoante da bibliografia especializada, que insiste na especificidade e autonomia do percurso de cada um deles, parece importante restabelecer os vínculos entre ambos, ressaltando o ritmo empresarial que ambos imprimiram à prática profissional em São Paulo, a carreira e o papel de cada um dos sócios na sociedade, e os debates e transformações arquitetônicas em curso na cidade no alvorecer do século XX.

0 estudo simultâneo de suas trajetórias mostra que a biografia de ambos apresenta uma série de coincidências relevantes. Como Severo, Ramos de Azevedo era filho de um negociante português, se casou com uma jovem de família abastada e influente de fazendeiros paulistas, tendo ascendido rapidamente à "fina flor" da oligarquia cafeeira. Projetaria palacetes luxuosos, chegando igualmente a participar do seleto circuito de investimentos e intermediação de contratos, encomendas e favores públicos de toda espécie,

45 Segundo Cândido Campos Neto, a Superintendência de Obras estadual era subordinada à Secretaria de Agricultura, Comércio e Obras Públicas, dedicada ao aparelhamento material do estado de São Paulo. As intervenções urbanísticas [nesse momento] eram vistas como aspecto indissociável de um processo econômico baseado na agricultura e apoiado pela atividade comercial" . Campos Neto, Candido Malta. Os Rumos da Cidade: Urbanismo e Modernização em São Paulo. São Paulo, Editora do SENAC, 2002, p. 60.

46 Lemos, Carlos A. C., Op. cit., 1993. p. 61. Severo, Ricardo. Op. cit., 1930, p. 10 
seja como empresário, seja nas instituições de cultura e no mundo das artes com que se envolveu intensamente. ${ }^{47}$

Severo torna-se sócio do arquiteto no ano de seu retorno à capital paulista e apenas um ano depois da reestruturação que Ramos empreendera em seu escritório, de modo a organizá-lo em bases empresarias. 0 arquiteto transformara o escritório em uma empresa de projeto e de construção que funcionava como núcleo central de um verdadeiro conglomerado de negócios imobiliários, produção e comércio de materiais de construção, agenciamento e intermediação de contratos e encomendas. ${ }^{48}$ A partir desse momento, sua carreira foi impulsionada a tal ponto que Ramos passaria da condição de arquiteto renomado e laureado entre seus pares para a de maior e quase exclusivo construtor de obras públicas no período. ${ }^{49}$

Não parece exagerado supor que Ramos tenha recebido neste momento a ajuda de seus sócios, Domiziano Rossi e Ricardo Severo. Ao que tudo indica Severo ocuparia um papel de destaque na administração do escritório ao se envolver com as questões financeiras e de relações públicas da empresa, deixando em segundo plano os projetos e as obras. ${ }^{50}$ É possível que a formação que recebera na Academia Politécnica do Porto, sobretudo do curso de Engenharia Civil de Obras Públicas, o tenha qualificado para exercer com competência as atividades não só de construção, mas também de administração. Isso porque o ensino da engenharia no período tinha como objetivo principal a formação de profissionais capacitados para as atividades de fomento de obras públicas e administrativas com vistas no gerenciamento e controle dos negócios coloniais na África. ${ }^{51}$

Em 1930, ao recapitular a sua atuação ao lado de Ramos, o engenheiro português incluiria o acompanhamento

47 Segundo Sérgio Miceli, Ramos de Azevedo ilustra com perfeição "esse tripé de funções políticas, empresariais e técnicas, indispensável ao exercício profissional de encargos e responsabilidades no espaço da classe dirigente ilustrada." Miceli focaliza o seu papel no mecenato e no colecionismo de arte e bens culturais em São Paulo, como típico representante de uma elite perrepista de perfil convencional e gosto acadêmico. Cf. Miceli, Sérgio. Nacional Estrangeiro, São Paulo, Companhia das Letras, 2003, pp.27-42.

48 Sobre o Escritório Técnico Ramos de Azevedo e seus colaboradores ver Fischer, Sylvia. Os Arquitetos da Poli. São Paulo, Edusp. 2005; Lemos, Carlos A. C., Op. cit., 1993; Carvalho, Maria Cristina Wolff, Op. cit.

49 Lemos, Carlos A. C., op. cit, 1993, p. 55

50 Idem, ibidem, p. 60

51 Rodrigues, Maria de Lurdes, Op. cit., p. 74. 
de praticamente todas as obras normalmente destacadas pela bibliografia como de responsabilidade do Escritório Técnico e notabilizadas pela assinatura de seu fundador: entre elas, as Secretarias de Agricultura e Fazenda, o Palácio da Justiça, a Escola Normal, a Escola Politécnica, o Liceu de Artes e Ofícios de São Paulo e de Campinas, a Faculdade de Medicina, o Quartel da Luz, a Penitenciária do Estado, o edifício dos Correios e Telégrafos, o Teatro Municipal e uma longa série de palacetes construídos em Higienópolis e nas avenidas Paulista, Angélica e Brigadeiro Luis Antônio ${ }^{52}$. A afirmação é problemática pois muitas dessas obras foram construídas durante a sua primeira estadia em São Paulo - quando ele ainda não era sócio de Ramos -, outras, iniciadas quando ele ainda estava em Portugal e outras ainda, terminadas quando o engenheiro já tinha retornado a capital paulista ou realizadas depois da morte de Ramos.

0 que interessa destacar, no entanto, é o sentimento de Severo de ter sido parte integrante e responsável pelas obras mais características do Escritório Técnico, cujas tradições dizia procurar manter "com os preceitos [daquele] grande Mestre da Arte de construir”, pleiteando não apenas a sua autoria, como a continuidade da obra do engenheiroarquiteto campineiro. De certo modo, Severo estava correto, pois o prestígio alcançado pelo escritório se preservou mesmo depois da morte de seu fundador em 1928, quando assumiu a direção do escritório ao lado do sobrinho e genro de Ramos de Azevedo, Arnaldo Dumont Villares ${ }^{53}$ e de seu filho, Antônio Severo. ${ }^{54}$ Este acontecimento tão decisivo não

52 Severo, Ricardo, Op. cit., 1930, pp. 10-11.

53 Arnaldo Dumond Villares, filho de Guilherme Villares e Virginia Santos Dumont, irmã da esposa de Severo, casou-se com Laura Lacaze Ramos de Azevedo, filha de Ramos de Azevedo em 1912. Ribeiro, Anamaria Germano, op. cit., 1998.

540 nome de Ramos de Azevedo a frente da empresa só desapareceu 10 anos depois, quando esta passou a se chamar simplesmente Severo \&t Villares Cia Ltda. Em sua última fase - da morte de Ricardo Severo até os anos 1970-80 - a empresa era dirigida por Arnaldo Dumont Villares, falecido em 1965 e Antônio Severo, segundo Luis Saia arquiteto formado pela Escola Nacional de Belas Artes do Rio de Janeiro na mesma turma de Oscar Niemeyer e coordenador da sessão de projetos do escritório desde os anos 1930. A empresa Severo \&t Villares fazia projetos em São Paulo e no Rio de Janeiro. Segundo Carlos Lemos, nos anos 1980 não passava de um mero escritório de administração e bens imobiliários, tendo sido vendido em 1991 a holding Partisil. 0 acervo do Escritório Técnico Ramos de Azevedo e da Severo \&t Villares Cia Ltda foi doado para a biblioteca da FAUUSP. Carlos A. C. Lemos, Catálogo de desenhos da biblioteca da FAU-USP. São Paulo, FAU-USP, 1998, p. 14; Lemos, Carlos A.C., Op. cit., 1993, pp 59-60 e nota 60; Saia, Luis. "Arquitetura paulista”, Xavier, Alberto (org.). Depoimento de uma geração. São Paulo, Cosacnaify, 2003. 
teria alterado o ritmo de produção da empresa, que até meados dos anos 1950 continuaria a ser reconhecida "não só pela categoria de seus projetos mas, principalmente, pela alta qualidade técnica construtiva" de suas obras. ${ }^{55}$

Entre as empresas que gravitavam ao redor do Escritório Técnico, Severo era acionista da Companhia Cerâmica Villa Prudente e da Companhia Iniciadora Predial. Esta última, fundada em 1908 por Ramos, Severo, Frederico Vergueiro Steidel e Arnaldo Vieira de Carvalho, era uma espécie de banco de financiamento imobiliário que construía residências de aluguel e financiava a construção de residências particulares ${ }^{56}$, destinadas à classe média ou àqueles que não podiam pagar nem construir os requintados palacetes concebidos no Escritório Técnico. Ricardo Severo dirigiu a companhia desde a sua fundação até 1940, quando veio a falecer, concentrando nessa empresa os seus conhecidos projetos neocoloniais. ${ }^{57}$

Severo também participou ativamente de outra entidade de fundamental importância para o funcionamento das empresas de Ramos de Azevedo, o Liceu de Artes e Ofícios de São Paulo. De 1909, quando entrou para a instituição, até 1928, o engenheiro português desempenhou no Liceu as funções de secretário e inspetor escolar, assumindo a direção da instituição após a morte de Ramos de Azevedo. Assim, também ali, a sucessão seria desempenhada por Severo, que exerceu o cargo de diretor até sua morte e manteve a orientação da instituição de formar não apenas artesãos, operários e técnicos, mas também artistas. ${ }^{58}$

Acompanhando a sua variada atividade no meio empresarial e institucional local, percebe-se que Ricardo Severo, além de sócio ativo, foi continuador da obra que Ramos de Azevedo edificara a partir do final do século XIX e que transformara profundamente o cenário arquitetônico da capital paulista, apagando sua feição colonial e tornando-a uma capital "atualizada", seguindo os moldes das cidades européias de feição eclética e universalista. Curiosamente, como se vê, foi no interior deste processo de modernização capitalista e beaux-arts da cidade, que transformou sua paisagem arquitetônica, pública e burguesa,

55 Lemos, Carlos A. C., Catálogo de desenhos da biblioteca da FAU-USP, p. 14. 56 Sobre o escritório de Ramos de Azevedo ver Lemos, Carlos A. C., op. cit., 1993. 57Idem, ibidem., p. 4-11.

58 Severo, Ricardo. Liceu de Artes e Ofícios. São Paulo: S.N., 1934; Gitahy, Maria Lucia. "Qualificação e urbanização em SP: a experiência do Liceu de Artes e Ofícios, 1873-1934". Ribeiro, M.A.R. Trabalhadores urbanos e ensino profissional. Campinas,:Ed. da UNICAMP, 1986, pp. 21-88. 
dando-lhe um caráter cosmopolita, para muitos, como o próprio engenheiro, demasiadamente estrangeiro, que Severo se tornou o chefe de fila da arquitetura "tradicional" no Brasil, de caráter nacional.

Essa aparente contradição entre sua atuação no Escritório Técnico e na "campanha tradicionalista", assim como as incongruências de seu discurso demonstram que a questão, de fato, não estava resolvida para Severo. Afirmando ter aproveitado a "prestigiosa influência do Escritório Técnico para lançar a "orientação tradicionalista" na arquitetura", Severo, de um lado, criticava veementemente o ecletismo exótico ao meio "racial e mesológico brasileiro" e por outro, deixava uma porta aberta a esta arquitetura, considerando-a adequada ao edifício de exceção, aqueles que, diferentemente da casa, não configurariam a feição "tradicional" das cidades. ${ }^{59}$

A incoerência do discurso e da prática arquitetônica de Severo aponta para a ambivalência do engenheiro na definição do nacional/estrangeiro, local/universal, tradicional/cosmopolita, mostrando que esta era uma questão em aberto. Presente na obra de arquitetos como Heitor de Melo, Archimedes Memória (1893-1960), Francisque Cuchet, Lucio Costa (1902-1998), Victor Dubugras (18681933) e no discurso de intelectuais como Menotti del Picchia (1892-1988), Monteiro Lobato (1884-1948), Mário de Andrade (1893-1945), entre outros, esta ambivalência revela o quadro de intensa disputa em torno da construção da modernidade, universalidade e/ou nacionalidade artística entre nós naquele momento. ${ }^{60}$

\section{Imprensa, cultura e nacionalismo}

A rápida inserção de Ricardo Severo nos meios sociais, empresariais e culturais paulistanos pode ser entendida, de um lado, a partir de seu casamento com Francisca Santos Dumont e, de outro lado, por sua associação com Ramos de Azevedo. Contudo, o engenheiro português não ficou restrito nem a esse círculo familiar e profissional, nem àquele composto por sua colônia. Tão logo se estabeleceu definitivamente na cidade, Severo começou a ampliar as suas relações, aproximando-se dos intelectuais que gravitavam ao redor do Instituto Histórico

59 Severo, Ricardo. "A Arte Tradicional no Brasil: a casa e o templo" (1914). Sociedade de Cultura Artística. Conferências 1914-1915. São Paulo, Tipographia Levi, 1916, p. 43-44.

60 Candido, Antonio. "Literatura e cultura de 1900 a 1945. (Panorama para estrangeiros)". Literatura e sociedade. Estudos de teoria e história literária. São Paulo, T. A. Queiroz Editor, 2000. 
e Geográfico de São Paulo (IHGSP) ${ }^{61}$ e do jornal $O$ Estado de S. Paulo. São justamente esses vínculos que, somados aos destacados anteriormente, ajudam a compreender o contexto e a repercussão da "campanha de arte tradicional" no Brasil encabeçada por Severo a partir de 1914.

0 engenheiro português se associou ao IHGSP em 1911, proferindo uma série de conferências entre esta data e os anos 1930. Na primeira delas, intitulada "Culto à tradição" (1911), Severo discorreu sobre o trabalho desenvolvido no Instituto, classificando-o como uma verdadeira "obra de concentração nacionalista, de resistência defensiva contra o cosmopolitismo destruidor das unidades cristalinas que representam no mundo humano as nações". ${ }^{62}$. Obra com a qual pretendia contribuir através da recuperação e veneração das tradições nacionais brasileiras, tão inseparavelmente ligadas às de seu país. Na segunda, intitulada "Origens da Nacionalidade Portuguesa" (1911) recuperava parte de seus estudos arqueológicos em Portugal, bem como suas teses acerca da evolução da nacionalidade portuguesa. Na última delas, realizada em 1932 durante o evento "Conferências Vicentinas", promovido em comemoração ao IV Centenário da Fundação de S. Vicente (1532), Severo abordava o problema das "Origens e fatos da expansão portuguesa no Brasil até 1530". ${ }^{63}$ As conferências de Severo, claramente comprometidas com a divulgação e valorização da nação portuguesa e de seu legado colonial no Brasil, somavam-se ao esforço de compreensão da formação das elites coloniais e da especificidade brasileira, empreendido pelo IHGSP. ${ }^{64}$

A preocupação com o nacional parece ser a chave da relação entre o engenheiro português e o assim chamado grupo d'O Estado de S. Paulo. Entendido por alguns autores como o maior núcleo nacionalista existente na cidade naquele momento ${ }^{65}, 0$ Estado fazia a defesa do "nacional"

61 Sobre o Instituto Histórico e Geográfico de São Paulo ver Schwarcz, Lilia Moritz. O Espetáculo das Raças: Cientistas, Instituições e Questão Racial no Brasil 1870-1930. São Paulo, Companhia das Letras, 1993.

62 Academia Paulista de Letras, Homenagem a Ricardo Severo: Centenário do seu Nascimento 1869-1969. São Paulo, SN, 1969, p 52.

63 Severo, Ricardo. "Origens e fatos da expansão portuguesa no Brasil até 1530” Revista do Instituto Geográfico e Histórico de São Paulo, 1932, n . 29, p 13-37.

64 Schwarcz, Lilia Moritz. Op.cit., p. 127. Ver também Santos, Fábio Lopes de Souza. Modernismo e Visibilidade: Relações entre as Artes Plásticas e a Arquitetura. Dissertação de Mestrado, FAU/USP, 2000.

65 Chiarelli, Tadeu. Um Jeca nos Vernissages: Monteiro Lobato e o Desejo de um Arte Nacional no Brasil. São Paulo, Edusp, 1995, p. 93. 
sem desconsiderar o legado português ${ }^{66}$, tão caro ao nosso engenheiro. Em evento organizado pelo Clube Português de São Paulo, em janeiro de 1929, na qual foram entregues insígnias do Governo Português para Julio de Mesquita Filho, Roberto Moreira e Nestor Rangel Pestana - principais acionistas e diretores d'O Estado -, Severo chamava atenção para o fato do jornal ter sido desde sempre um veículo aberto para suas idéias, prestando enormes serviços à colônia portuguesa. ${ }^{67}$ De fato, entre os anos de 1908 e 1940 , Severo publicou dezenas de artigos naquele jornal ${ }^{68}$, que abrangiam desde temas relacionados à colônia portuguesa e ao Liceu de Artes e Ofícios até aqueles dedicados especificamente à sua "campanha de arte tradicional". As suas relações com o jornal, entretanto, não eram apenas profissionais ou intermediadas pela colônia. Severo era amigo pessoal de Júlio de Mesquita e Rangel Pestana, projetando para o primeiro uma residência em "estilo tradicional", e com ele compartilhando da companhia do segundo nas diversas iniciativas culturais que desempenharam em torno do jornal ${ }^{69}$, como, por exemplo a Revista do Brasil e a Sociedade de Cultura Artística.

A preocupação d'O Estado com o nacional de modo geral definiu o caráter de boa parte desta crítica de arte local em formação ${ }^{70}$, fossem elas "de serviço" ou "militante", estando presente também na publicação de contos regionais, como os de Waldomiro Silveira, ou na seção

66 Martins, Wilson. História da Inteligência Brasileira. Vol.VI (1915-1933). São Paulo, Cultrix/ Edusp, 1978, p. 74.

67 Discurso de Ricardo Severo no referido evento, publicado n'O Estado de S. Paulo, 27/01/1929.

68 Neves, João Alves das. As Relações Literárias de Portugal com o Brasil. Lisboa, Instituto de Cultura e Língua Portuguesa, 1992, Santos, Paulo. "A presença de Lucio Costa na arquitetura contemporânea no Brasil”. Rio de Janeiro, 1960, nota 16.

69 Sobre a casa de Júlio de Mesquita ver Homem, Maria Cecília Naclério. O Palacete Paulistano e outras Formas Urbanas de Morar da Elite Cafeeira 1867-1918. São Paulo, Martins Fontes, 1996, pp. 233-246.

70 Tadeu Chiarelli divide essas críticas entre crítica de serviço, cujo propósito central era o de informar o leitor acerca das exposições e artistas presentes na cidade, e a crítica de arte militante, que revelaria "o desejo de intervir decisivamente na cena artístico-cultural, propondo sua transformação, sempre a partir de um parâmetro ético, estranho à especificidade artística - no caso, o forte nacionalismo" e que começaria a ser veiculada somente a partir de meados da década de 1910. Segundo o autor a partir de 1913 muitas das crônicas de serviço eram escritas por Nestor Rangel Pestana, redator do jornal desde os primeiros anos do século e seu diretor a partir da morte de Júlio de Mesquita em 1927. Chiarelli, Tadeu. op. cit.., pp. 69-106. 
“Tradições populares", na qual Amadeu Amaral divulgou os seus famosos ensaios sobre a cultura popular paulistana e brasileira. ${ }^{71}$ Essa mesma preocupação orientou os jornalistas e intelectuais ligados ao grupo na criação de associações culturais e cívicas, como a Sociedade de Cultura Artística e a Revista do Brasil. Nessas outras duas frentes nacionalistas no campo da cultura, também a participação de Ricardo Severo foi marcante.

A Sociedade de Cultura Artística, fundada em 1912, foi a primeira associação cultural paulistana fortemente marcada pela necessidade de valorizar a cultura nacional. Foi justamente com este intuito que se organizaram no seu interior uma série de saraus lítero-musicais, além de palestras sobre artes plásticas e arquitetura. A antológica conferência "A Arte Tradicional no Brasil""2, proferida por Ricardo Severo em julho de 1914, integrava uma dessas séries de conferências realizadas na sociedade. De acordo com Tadeu Chiarelli, esta primeira conferência de Severo teria antecipado, ao lado de Oswald de Andrade (1890-1954) e de seu artigo "Em prol de uma pintura nacional" (1915), o papel e os objetivos da crítica militante na defesa de uma arte e arquitetura nacionais. Para o crítico, a conferência teria manifestado não apenas o desejo de uma arte nacional, mas também a configuração de um programa para ela, cuja proposta central era pensar uma arte brasileira futura a partir do estudo e da reflexão sobre o passado nacional. ${ }^{73}$

Esse duplo comprometimento, de um lado com o estudo e valorização do passado e das tradições nacionais, e de outro, com a proposição de uma arte nacional presente e futura - que se evidencia em todos os textos da "campanha de arte tradicional” de Ricardo Severo -, definia também o programa artístico-cultural da Revista do Brasil, mensário de ciências, letras, artes, história e atualidade, idealizado por Júlio de Mesquita e lançado em janeiro de 1916 em São Paulo. A revista, que se tornou a mais prestigiada publicação cultural da República Velha, pertenceu até 1918 a uma sociedade anônima cuja diretoria era composta por vários jornalistas e colaboradores d'O Estado, dentre eles Ricardo Severo, seu presidente. ${ }^{74}$

71Idem, ibidem., p. 93.

72 Severo, Ricardo, op. cit., 1916, p. 37-82.

73 Chiarelli, Tadeu, op. cit., p. 96.

74 Severo, Ricardo. “A Arte Tradicional no Brasil”. Revista do Brasil. São Paulo, ano I, n. 1, jan/ 1917, pp. 394-424. 
Se das páginas da revista emerge claramente esse desejo persistente de promover uma releitura do país que resultasse numa ação de sentido regenerador ou identitário, não é possível afirmar que "a proposição do problema, a maneira de enfrentá-lo e as saídas sugeridas" fossem homogêneas. ${ }^{75}$ Recuperar a tradição nacional e mais do que isso uma tradição que sintetizasse o país enquanto nação não era uma tarefa nada fácil, mas extremamente polêmica. A questão que despontava nas páginas da revista, tão bem colocada por Alceu Amoroso Lima, era a seguinte: "Deve um povo em plena mocidade prezar suas tradições? Ou, pelo contrário, esquecer o passado para melhor encarar o futuro?"76

Se alguns propunham veementemente "o esquecimento do passado em prol das tarefas impostas pelo futuro [, sugerindo] que simplesmente se desconsiderasse o 1500 e se tomasse a Independência como marco inaugural da nossa história, negando dessa forma, qualquer sentido ou pertinência ao período colonial" outros defendiam apaixonadamente as tradições, procurando ao contrário valorizar e redimir nosso passado colonial ${ }^{77}$. Ricardo Severo e seu culto à tradição se encaixam perfeitamente neste último grupo.

A campanha de arte tradicional: arqueologia, etnografia e arte Foi em meio a esse ambiente nacionalista, acirrado pela conflagração mundial e pelas comemorações do centenário da independência do Brasil, que a "campanha de arte tradicional" no Brasil lançada por Severo começou a tomar forma. A campanha coincide com uma série de movimentos artísticos de cunho nacionalista em curso na América Latina, Caribe, Estados Unidos e Europa, dos quais poderíamos citar o neocolonial ${ }^{78}$, a arquitetura hispânica ou mission style ${ }^{79}$, liberty e o art nouveau em países como a Es-

75 Luca, Tânia Regina de. A Revista do Brasil: um Diagnóstico para a (N) ação. São Paulo, Editora da UNESP, 1999, p. 78.

76 Apud idem, ibidem., p. 90

77 Idem, ibidem, p. 85-130

78 Amaral, Aracy, (org.), Arquitectura Neocolonial: América Latina, Caribe, Estados Unidos. São Paulo, Memorial da América Latina/ Fondo de Cultura Económica, 1994.

79 Scully, Vincent, The Shingle Style and the Stick Style. New Haven, Yale University Press, 1971; Wilson, Chris. The Myth of Santa Fe: Creating a Modern Regional Tradition. New Mexico,University of New Mexico Press, 1997. 
cócia, a Bélgica, a Finlândia ou a Alemanha ${ }^{80}$, sem contar o da casa portuguesa, liderado por Raul Lino (1879-1974). ${ }^{81}$ No caso de Severo é possível reconhecer, ao lado das motivações ideológicas, políticas e nacionalistas que o levaram a propor a recuperação do passado colonial brasileiro e de seu legado português, o interesse pronunciado pela história da arquitetura, o estabelecimento de uma relação operativa entre o passado e o presente e o desejo de criar um estilo nacional, independente da tradição clássica, características que marcaram os revivals deste período. ${ }^{82}$ Além disso, em seu discurso é patente a preocupação com a atualização das tradições e a modernização, ou adequação, dos edifícios às novas necessidades físico-espaciais e técnico-construtivas da sociedade naquele momento.

0 termo "campanha" só foi empregado pelo engenheiro português a partir de $1922^{83}$, entretanto, olhando retrospectivamente é possivel afirmar que as conferências e projetos anteriores a esta data também fazem parte

80 Sobre o liberty e Art Nouveau nestes países ver Curtis, William. "The search for new forms and the problem of ornament”. Modern Architecture since 1900. London, Phaidon Press Limited, 1999, pp. 53-71; Frampton, Kenneth. História Crítica da Arquitetura Moderna. São Paulo, Martins Fontes, 1997, capítulos 4, 5 e 6; Escritt, Stephen. Art Nouveau. London, Phaidon, 2000.

81 Raul Lino é contemporâneo de Severo e como ele manteve relações com o Brasil. Em Portugal era considerado um dos arquitetos portugueses de maior renome naquele momento a defender "sem hesitações a recuperação das 'formas portuguesas', num percurso 'nacional', alternativo à produção eclética novecentista”. Sobre o tema ver: Gonçalves, José Fernando. Ser ou Não Ser Moderno. Considerações sobre a Arquitetura Modernista Portuguesa. Coimbra, Departamento de Arquitetura da Faculdade de Ciências e Tecnologia da Universidade de Coimbra, 2002, p.60-68; França, José Augusto. "Raul Lino e a 'casa portuguesa' ". A Arte em Portugal no Século XIX. Lisboa, Livraria Bertrand, 1966; Campos, Isis Alexandra Marques. Raul Lino (1879-1974). A Casa Popular Portuguesa e o seu Caráter Proletário. Trabalho de disciplina FAU-USP, 2003 (mimeo); Santos, Paulo Ferreira. Presença de Lucio Costa na Arquitetura Contemporânea do Brasil. Conferência, 1960, nota 15.

82 Patetta, Luciano. "Los revivals en arquitectura". ARGAN, Giulio Carlo et alt. El Passado em el Presente: el Revival en las Artes Plásticas, la Arquitetctura, el Cine y el Teatro. Barcelona, Editorial Gustavo Gili, 1977, pp. 129-163 e Argan, Giulio Carlo. "El revival".ARGAN, Giulio Carlo et allii, op. cit., p. 7-28.

830 termo campanha só aparece textualmente no artigo "Da Arquitetura Colonial no Brasil: arqueologia e arte", publicado em 7 de setembro de 1922 n'O Estado de S. Paulo, em razão das comemorações do centenário da independência do Brasil. 
desta iniciativa ${ }^{84}$, tanto pelo teor, quanto pelo tom propositivo que as caracterizam. 0 levantamento de seus projetos e textos "tradicionalistas" revela que a campanha em prol da arte "tradicional" no Brasil se concentrou nas décadas de 1910 e 1920, mas que seu discurso e sua prática extrapolam os limites temporais como espaciais normalmente definidos pela bibliografia especializada sobre o neocolonial. Desta forma, o estudo das relações entre as campanhas tradicionais lideradas por Severo no Porto e em São Paulo, propaladas, pelo próprio engenheiro, se revela fundamental.

Os motivos que levaram Ricardo Severo a lançar sua "campanha tradicionalista" no Brasil são diversos, mas absolutamente intrincados. Seu interesse pela arquitetura do período colonial, sua intenção de fazer uma arte "tradicional" brasileira que congregasse o velho e o novo, o português e o brasileiro, sua pretensão de desvendar as origens da arquitetura brasileira e, através dela, as da nacionalidade, eram alinhavados pelo intuito deliberado de valorizar a herança lusitana. Não parece ser à toa que tanto a animação quanto o arrefecimento de sua campanha coincida com o esfriamento de sua proposta associativa luso-brasileira, também levada a cabo entre os anos 1910 e 1920.

0 eixo central de sua campanha era a discussão acerca das origens, desenvolvimento e características da "arquitetura tradicional brasileira". Desde suas primeiras manifestações sobre o tema, o engenheiro tomava as antigas e modestas construções do período colonial como vestígios poderosos de identificação do momento original de "formação" desta jovem nação, considerando-os tão reveladores e dignos de nota quanto haviam sido os antigos fósseis por ele pesquisados em Portugal. Atribuindo àquelas

84 Textos e projetos da campanha: "Culto à Tradição" (1911) e das conferências a "Arte Tradicional no Brasil" (1914/ 1916), ao quais poderíamos acrescentar os artigos "Arquitetura Velha" (1916), "Da Arquitetura Colonial no Brasil: arqueologia e arte" (1922); a entrevista "Arte Colonial III" (1926 ) para o jornal O Estado de São Paulo, além do artigo "A casa da faculdade de direito de São Paulo 1634-1937" (1938); "Palacete Numa de Oliveira" (1916), a "Casa Lusa"(1920-24), os edifícios do "Banco Português", da "Portuguesa Beneficente de Santos e Campinas" (1926), a "restauração da Igreja da ordem terceira do Carmo", e por último o projeto para o "Congresso do Estado de São Paulo" (1929), aos quais reunimos apoiados na bibliografia específica e na análise dos projetos, a "Casa do Porto" (1900), a "Casa Julio de Mesquita” (contemporânea a Numa de Oliveira), a “Casa Praiana" (1921), o "Pavilhão das Indústrias de Portugal” (1922-23), a "Casa José Moreira" (1926), a "Sociedade de Cultura Artística" (1926), a "Faculdade de Direito do Largo São Francisco" (1932) e a "Casa Rui Nogueira" (1939-40) 
construções a capacidade de terem cristalizado perfeitamente as manifestações mais primitivas de nosso povo, ou numa palavra, nossa tradição, Severo acreditava poder recuperar através delas o nascimento e desenvolvimento da nacionalidade brasileira e assim descobrir suas verdadeiras origens étnicas. Entretanto, ainda que enfatizasse a importância seminal das manifestações populares no campo das artes e arquitetura, estas não seriam, como veremos a seguir, nem objeto de estudo mais detido em seus textos de campanha, nem mote de inspiração para seus projetos.

0 vínculo determinante entre nacionalidade, meio e manifestações artísticas defendido por Severo, fazia com que ele afirmasse o caráter etnográfico da arte, sobretudo a "tradicional", apontando na conferência "A Arte Tradicional no Brasil" de 1916, assim como no título do artigo "Da arquitetura colonial no Brasil: arqueologia e arte" (1922), para a inevitabilidade de se fazer história da arte como se esta fosse arqueologia.

Para Severo, a arqueologia conferia ao estudo da arquitetura a possibilidade de recompor através dos mais rudimentares documentos não apenas a sua história, como a da própria "civilização brasileira" ${ }^{85}$ Desse modo, ao escrever a história da arquitetura do Brasil o engenheiro construía ao mesmo tempo a história da nacionalidade brasileira, fazendo com que ambas fossem absolutamente inseparáveis. É por isso que não podemos esquecer que, para ele, a busca dos fundamentos desta nacionalidade e de sua arte "tradicional" estavam intimamente ligadas à campanha de valorização da herança colonial lusitana, e a partir dela, da própria nacionalidade portuguesa. É justamente este seu comprometimento que guiará em grande medida sua leitura da arquitetura brasileira, como a de Portugal, e que explicará a valorização ou negação deste ou daquele estilo arquitetônico, tanto historicamente quanto do ponto de vista artístico. Em seu arraigado nacionalismo, ou antes, veemente lusitanismo, Severo validava apenas aquela arquitetura que representava para ele a "perfeita cristalização da nacionalidade" portuguesa, e de seus desdobramentos no novo mundo.

0 ponto de partida de sua genealogia étnico-artística era o "período histórico da colonização portuguesa". Como em seu discurso racial, a ascendência lusitana era supervalorizada em detrimento das contribuições, ou mesmo, da 85 Severo, Ricardo, op. cit., 1917, p. 400. 
participação dos índios, negros e outros povos imigrantes na construção do mundo colonial e, no fundo, da própria nação, ainda que, ao se referir a matriz étnica desta arquitetura, reconhecesse a influência romana, árabe, moura e chinesa. Se com relação aos indígenas, considerava que as suas manifestações artísticas, "pelo seu caráter e simbolismo original, se prestam a novas expressões estéticas"; afirmava que estas não seriam, "porém tradicionais, se bem que caracteristicamente autóctones" e, portanto, estranhas no meio da "família brasileira" ${ }^{86}$. Com relação aos negros, suas referências não passariam de um breve comentário sobre a escravidão, no qual o engenheiro se opunha à idéia de que esta teria sido no Brasil, pelas mãos dos portugueses, de uma "barbárie" e "crueldade" sem tamanho ${ }^{87}$. Quanto aos imigrantes de outras nacionalidades, eram definidos como "aventureiros" que não teriam se fixado à terra com o intuito de "constituir uma nova nação, moldada na sua original matriz étnica", como afinal haviam feito os colonizadores portugueses.

Partindo da matriz lusitana, Severo traçava a história da arquitetura "tradicional" brasileira, de sua fundação, desenvolvimento, desvirtuamento e retomada, a partir de uma periodização bastante interessada, que estabelecia quatro momentos mais ou menos definidos ${ }^{88}$ : o primeiro denominado "Brasil-Colônia", que ia do descobrimento até o final do século XVIII, quando experimentaríamos o desenvolvimento de uma arte verdadeiramente "tradicional"; o segundo, nomeado "Brasil-Monarquia", que se inauguraria no início do século XIX, com o primeiro momento de transformação e depois de "degenerescência" da arquitetura "tradicional” em função do advento da Missão Francesa, da fundação da Academia de Belas Artes, mas principalmente do "triunfo da independência" e do ecletismo; o terceiro, iniciado a partir de meados do XIX e denominado "BrasilRepública”, no qual a ferida aberta pela independência no curso "natural" de nossa arquitetura se aprofundaria, esta arte perdendo totalmente seu cunho nacional; e o último, em que as tradições eram retomadas dando início "a uma nova era de RENASCENÇA BRASILEIRA".

86Idem, ibidem, 1916, pp. 44-46.

87Idem, ibidem, 1917, p. 397.

88 Essa periodização está presente em todos os textos aqui selecionados, mas é mais clara e explícita nas conferências "A Arte Tradicional no Brasil" de 1914 e de 1916. 
A leitura de sua obra "tradicionalista" revela a existência de um diálogo entre Severo e outros intelectuais, artistas e arquitetos, igualmente preocupados com problema da nacionalização e internacionalização artística, tendo como palco preferencial de divulgação os jornais e revistas em circulação naquele período ${ }^{89}$. Ao mesmo tempo, a conversa entre eles aponta para o fato de que certas idéias eram menos fruto de uma ou outra inteligência especial, do que naturalização de conceitos dispersos no cotidiano, constituindo-se, portanto, em lugares comuns entre aqueles que se vinculavam a este ou aquele nacionalismo. Isso não quer dizer que não houvesse pontos de vistas diferentes sobre o mesmo tema ou que partissem de um mesmo ponto em comum, apenas que certas idéias se cristalizaram de tal maneira que ainda hoje se fazem presentes.

A despeito de suas realizações arquitetônicas, Severo revelava em seu discurso uma preocupação e um compromisso característico de sua época. ${ }^{90}$ Ao lado da preocupação

89 Souza, Ricardo Forjaz Christiano de. O Debate Arquitetônico Brasileiro, 1925-1936. Tese de doutorado, FFLCH-USP, 2004.

90 Em seu estudo sobre a arquitetura moderna William Curtis afirma que na passagem do século XIX para o XX os arquitetos, filiados aos mais diversos estilos - do ecletismo ao modernismo - reconheciam naquele momento um contexto comum de transformações profundas nos mais diversos campos da sociedade com o qual se debatiam e ao qual buscavam responder. As dúvidas eram muitas: como reconciliar o velho e o novo, o mecânico e o natural, o utilitário e o ideal, o nacional e o internacional? Como as formas de um novo estilo 'contemporâneo' poderiam ser descobertas? qual deveria ser o verdadeiro conteúdo" da arquitetura frente às transformações profundas geradas pela industrialização? As repostas dadas pelos arquitetos deste período foram muitas, à medida que tanto o ponto de partida para se repensar a arquitetura do presente quanto o que era entendido como característico da época podia variar conforme o arquiteto, a região e o país, além disso, nem todos os arquitetos e teóricos viam as transformações geradas pela industrialização de maneira positiva. 0 que estou tentando salientar na interpretação de Curtis - desenvolvida para um contexto diferente, o europeu e americano na virada do século XIX para o XX - é o tratamento dispensado à arquitetura não moderna daquele momento. Ao considerar um contexto e uma busca comum tanto para arquitetos ecléticos quanto modernos ele procurava validar também as investigações estéticas e arquitetônicas dos primeiros, normalmente descartadas como meras manifestações atrasadas e extemporâneas pela historiografia (moderna) da arquitetura. Algo que nos pareceu válido também para o estudo do neocolonial e do moderno nas primeiras décadas do século XX no Brasil. Veja, não se trata de não admitir o fato inconteste do salto estético e artístico dado pelo moderno naquele momento, mas de reconsiderar o neocolonial também como uma busca contemporânea, que deve ser entendida não a partir da arquitetura moderna, mas sim dentro de um dado contexto histórico e a partir de proposições estéticas específicas. Ver Curtis, William. Modern Architecture since 1900. London, Phaidon Press Limited, 1999, sobretudo a introdução e o capítulo 1 intitulado "The Idea of modern architecture in the nineteenth century”. 
em conhecer, estudar e recuperar esse passado, tanto o engenheiro português como aqueles que seriam seus companheiros, inimigos ou críticos intentavam fundar uma arquitetura nacional, presente e futura, que não significasse a retomada pura e simples do que havia sido realizado anteriormente, mas sim sua reinterpretação e atualização. A convicção de que as origens de nossa arquitetura nacional moravam no até então desprezado passado colonial era compartilhada, por exemplo, por personagens tão diversos quanto os engenheiros Ricardo Severo e Alexandre de Albuquerque (1880-1940) ${ }^{91}$, o médico e mecenas José Marianno Filho (1881-1946) ${ }^{92}$, os arquitetos Adolpho Morales de los Rios (1887-1973) ${ }^{93}$, Lucio Costa ${ }^{94}$ e Paulo Santos ${ }^{95}$, os escritores Monteiro Lobato (1884-1948) ${ }^{96}$, Mário de Andrade $^{97}$ e Manuel Bandeira (1886-1968) ${ }^{98}$, entre outros. Cer-

91 Engenheiro e professor da Escola Politécnica de São Paulo, envolvido ao mesmo tempo com a reconstrução da catedral da Sé em estilo gótico - defendido pelo engenheiro pelo caráter monumental da obra incompatível com a arquitetura colonial - e "excursões científicas para o estudo e levantamento de plantas dos tempos das casas coloniais". Ver Fischer, Sylvia, op. cit.

92 Principal promotor do neocolonial no Rio de Janeiro entre as décadas de 1920 e 1930. Ver Kessel, Carlos. Entre o Pastiche e a Modernidade: Arquitetura Neocolonial no Brasil. Tese de Doutorado, UFRJ, 2002.

93 Arquiteto espanhol, radicado no Brasil, que também se envolveu simultaneamente com a arquitetura eclética e neocolonial.

94 Após assumir a direção da Escola Nacional de Belas Artes em 1930, Lucio Costa filiasse a arquitetura moderna e a partir desse momento tornase um dos principais críticos neocolonial, movimento ao qual se vinculara desde os tempos de estudante. Ver Wisnik, Guilherme. Lucio Costa. São Paulo, Cosacnaify, 2001.

95 Contemporâneo de Lucio Costa, Paulo Santos também se vinculou ao neocolonial no início de sua carreira para depois de filiar a arquitetura moderna. No seu caso, entretanto, a crítica ao neocolonial não parece tão ferrenha quanto a promovida por Lucio Costa, a ponto do arquitetura estabelecer vínculos entre os dois movimentos. Ver Santos, Paulo Ferreira. A Influência do Neocolonial na Arquitetura Moderna do Brasil. Conferência no Instituto dos Arquitetos do Brasil, 1951.

96 Monteiro Lobato apoiou a campanha de arte tradicional de Ricardo Severo e sobre ela dedicou uma série de artigos. Ver Chiarelli, Tadeu. op. cit.

97 Intelectual que se vinculou ao neocolonial até o final da década de 1920, quando então reviu a sua posição e foi aos poucos se aproximando da arquitetura moderna. Severo, aliás, foi uma referência importante na construção de seu estudo sobre a arte religiosa no Brasil. Sobre as relações entre Mário, Severo e o neocolonial ver do próprio escritor A Arte religiosa no Brasil. São Paulo, Experimento/ Giordano, 1993; Aspectos das Artes Plásticas no Brasil. São Paulo, Martins/ Brasília, INL, 1975 e "Arquitetura Colonial". Arte em Revista, no. 4, ano 2, ago. 1980.

98 Ver Amaral, Aracy. Artes Plásticas na Semana de 22. São Paulo, Ed. 34, 1998. 
teza que animava e era alimentada por uma série de viagens de busca das fontes primitivas da cultura brasileira, que ocorreram entre as décadas de 1910 e 1920, e que não se restringiram ao meio arquitetônico. ${ }^{99}$ As viagens realizadas pelo pintor José Wasth Rodrigues (1891-1957) ${ }^{100}$ e os arquitetos Felizberto Razini (1881-1976) ${ }^{101}$ e Lucio Costa não foram as únicas, mas são exemplares do intuito central das incursões pelo país no campo da arquitetura. Além do desejo de conhecer e analisar a produção artística do passado, essas viagens tinham como objetivo procurar um manancial de inspiração que desse sustentação ao projeto romântico de constituição de uma arte que fosse ao mesmo tempo nacional e contemporânea. 0 que parecia interessar essencialmente aos artistas e intelectuais do período era a articulação entre as manifestações artísticas do passado com os projetos culturais que eles começavam a esboçar. ${ }^{102} \mathrm{E}$ aí a reconstituição de nossa história da arquitetura assumia um papel estratégico.

Nessa reconstituição, a prevalência de uma mesma periodização presente nos escritos de Severo, Wasth Rodrigues, José Marianno Filho, Mário de Andrade e Lucio Costa é curiosa. Para todos, nossa tradição arquitetônica fora lentamente se constituindo desde o descobrimento do Brasil, para desabrochar com toda exuberância e autenticidade entre os séculos XVII e XVIII, sobretudo em Minas Gerais. 0 verdadeiro caminho seguido pela arquitetura brasileira ao longo desse período, teria sido interrompido no século XIX por um ecletismo cosmopolita estranho ao "meio" e as "tradições" nacionais. As divergências começam a aparecer justamente neste ponto.

Para uns, como Severo e Marianno, a verdadeira atualização da arquitetura brasileira propiciada pela retomada do fio da meada "tradicional" interrompido com o ecletismo, se dava com aquilo que ficou conhecido como o neocolo-

99 Meyer, Marlyse. "Um Eterno Retorno: as Descobertas do Brasil”. Caminhos do Imaginário no Brasil. São Paulo, Edusp, 1993, p. 19-46.

100 De suas viagens resultou o livro, Rodrigues, José Wasth. Documentário Arquitetônico Relativo à Antiga Construção Civil no Brasil. Belo Horizonte: Ed. Itatiaia/ São Paulo: Edusp, 1979, publicado originalmente nos anos 1940.

101 Lemos, Carlos A, “0 Ecletismo em São Paulo". Ecletismo na Arquitetura Brasileira. São Paulo, Nobel/ Edusp, 1987, pp. 68-103.

102 Gomes Jr., Guilherme Simões. Palavra Peregrina: o Barroco e o Pensamento sobre as Artes e Letras no Brasil. São Paulo, Edusp, 1998. 
nial. Para outros, como Lucio Costa e Paulo Santos, isso só ocorreria de fato com o advento do moderno.

Outro ponto interessante de confronto se dá com relação à constituição étnica da arquitetura brasileira. Se em Severo a figura chave era a do colonizador português que no Brasil se aclimatara reinventando a arquitetura de sua terra natal conforme o clima e os meios disponíveis, em Mário de Andrade quem se sobressai é o mulato, especialmente representado por Aleijadinho e Valentim. ${ }^{103}$ Ademais, desde a viagem a Minas com Cendrars em 1924, o crítico vinha desenvolvendo o conceito de nacionalismo universalista, a partir do qual, "podia religar sem constrangimentos a informação européia de vanguarda com a pesquisa etnográfica, psicológica e folclórica mais atual". ${ }^{104}$ Mário, diferentemente de Severo, não via o estrangeiro como uma ameaça. Ele o pensava a partir de sua condição de ser brasileiro e, portanto com um ponto de vista outro que transformava a informação que chegava de outros países. Lucio Costa também enfatiza a contribuição dos negros, índios e mestiços no "amolecimento" da matriz arquitetônica portuguesa, notado por Gilberto Freyre em outros campos da vida nacional. ${ }^{105} \mathrm{E}$ como Mário, seria menos avesso à contribuição estrangeira que o engenheiro português e Marianno, desde que tal contribuição fosse bem assimilada.

As coincidências e divergências entre os discursos destes engenheiros, arquitetos, artistas, escritores e intelectuais, reforça a complexidade e a ambigüidade do debate acerca do moderno e do nacional no Brasil em curso na primeiras décadas do século XX. Em sua trajetória, Severo pa-

103 Andrade, Mário de. A Arte Religiosa no Brasil. São Paulo, Experimento/ Giordano, 1993; Idem, "Aleijadinho: posição histórica". O Jornal, Rio de Janeiro, ed. especial sobre Minas Gerais, 1928. Fernanda Peixoto faz ainda interessantes considerações, a partir da leitura de Roger Bastide e de seu "diálogo" com Mário de Andrade, sobre como este entendia o barroco e a constituição de uma arte brasileira. Sobre isto ver Peixoto, Fernanda Arêas. "Roger Bastide e o modernismo: diálogo interessantíssimo". Diálogos brasileiros: uma análise da obra de Roger Bastide, São Paulo, Edusp/ FAPESP, 2000, pp. 45-92.

104 Lira, José Tavares Correia de. Localismo Crítico e Atualidade na Arquitetura. Mário de Andrade e a informação moderna (1925-1929). Texto mimeografado, 2002.

105 Costa, Lucio. “Documentação Necessária”. Revista do Serviço do Patrimônio Histórico e Artístico Nacional. Rio de Janeiro, n. 1, 31/09/1937. Como aponta Henrique Mindlin em seu texto "Gilberto Freyre e os Arquitetos”. Arquitetura, São Paulo, 1962, n. 4, Freyre teve grande influência sobre os arquitetos modernos nas décadas de 1930/40, sobretudo no que diz respeito a definição do que seria a verdadeira arquitetura brasileira. 
rece justamente sintetizar e exibir lados e versões conflitantes naquele momento, aproximando a partir das noções de tradição, nação e modernização artística, movimentos que a princípio estariam em lados radicalmente opostos como o ecletismo, o neocolonial e o moderno, ou agentes tão distantes como os intelectuais do Instituto Histórico e Geográfico - que acolhem com entusiasmo suas idéias- e os modernistas paulistanos - que num primeiro momento o aclamam, para depois o criticarem. Se é possível perceber, por um lado, o quanto o moderno e o modernismo naquele momento reivindicam o novo e uma nova forma de falar sobre o Brasil beneficiando-se surpreendentemente de idéias e sugestões caras ao século XIX - como as de tradição e evolução, apenas para citar duas bastante influentes no período - por outro, fica clara a importância de se pensar a produção da época a partir de um solo de disputas em torno dessas e outras noções, no qual o campo de batalha é a arena social. 